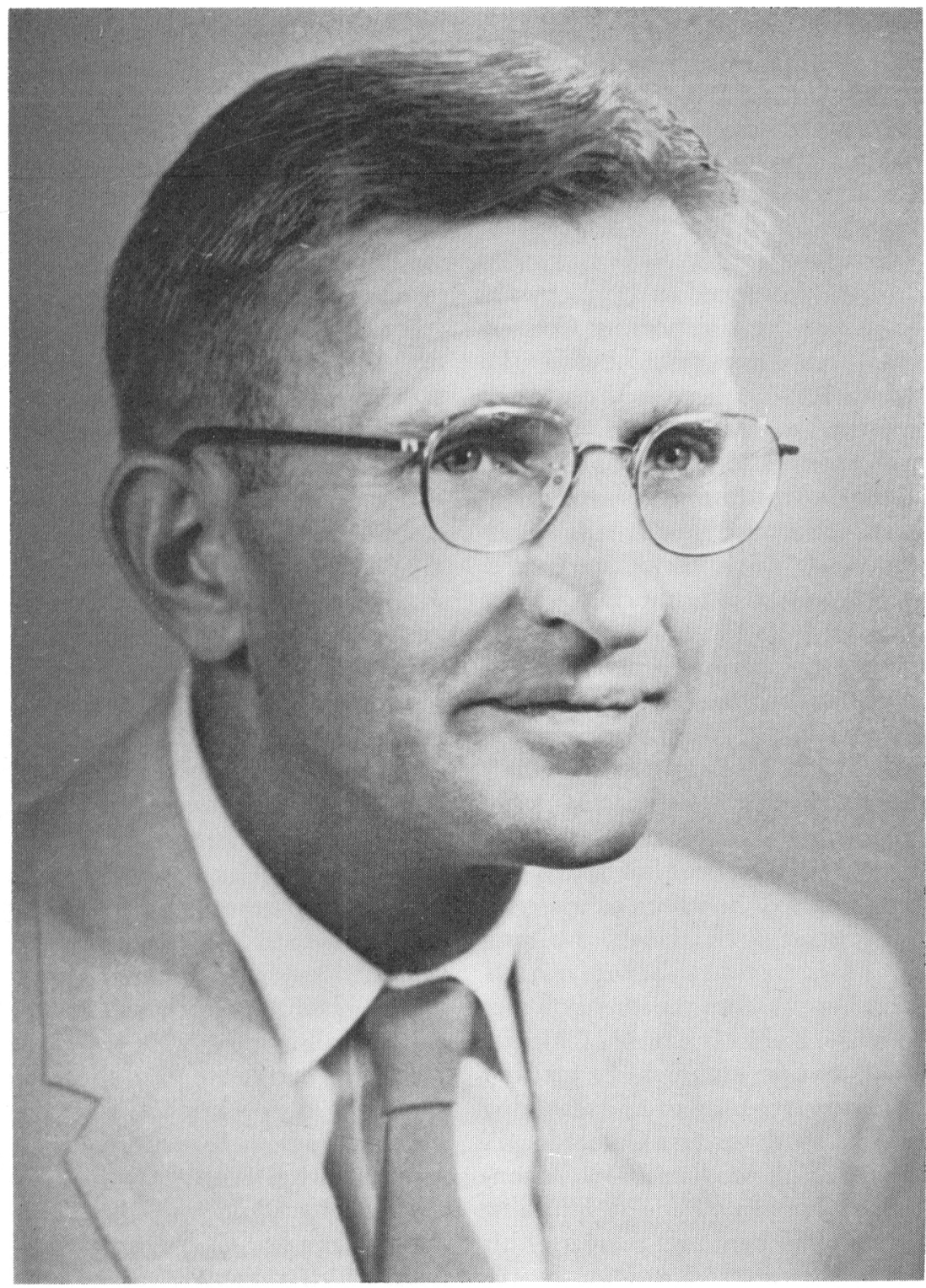

\title{
ROBERT FREDERICK BURGH
}

$$
\text { 1907-1962 }
$$

Robert Frederick Burgh died in Tucson, March 16, 1962, at the age of 54. During the last few years of his life he had found a happy refuge through the comforts and companionship of marriage and home and a return to the work that first drew him into the academic world. Before this final period lay a lifelong battle for health under the affliction of emphysema and allied troubles that had begun in childhood. In spite of this handicap he had been active for most of the past 30 years in many phases of archaeology in the Southwest, and was well known to a wide circle in his profession. 
The youngest of four sons of Frederic Daniel Burgh and Jane (Johnson) Burgh, Bob was born in Denver, December 23, 1907, but within a year was taken by his parents to a farm near the small town of Three Oaks, in southwestern Michigan. Here he attended the two-room rural school and later the high school at Three Oaks. After graduation Bob worked on the farm for two years, and in 1927 entered Purdue University in the Engineering College. At the end of his sophomore year, however, he was compelled to leave college because of ill health, and returned to Three Oaks, where he became general assistant at the Chamberlain Memorial Museum, an institution devoted mainly to the history, archaeology, and natural history of the region. It was directed by George Fox, who gave his young aide much guidance and encouragement.

This was the effective beginning of a career in archaeology, but its inception went back to an occasion in October, 1927, to a meeting at the Chamberlain Memorial Museum at which Carl E. Guthe of the University of Michigan Museum had been present. It was largely through Guthe's inspiration and advice that the young farm boy was encouraged to enter college and subsequently to pursue archaeology as a profession.

In 1931 at another museum meeting Bob met Paul S. Martin of the Field Museum of Chicago, who employed him that summer on his first field excursion as surveyor for a party excavating the Lowry Ruin in southwestern Colorado. A second season there followed in 1933. Meanwhile in 1932 Bob had been a Ranger-Naturalist at Mesa Verde National Park and thereafter his feet were deep in the sands of the Southwest, despite many interruptions and excursions elsewhere. For almost three years he was employed in various capacities - surveying, mapping, ruin stabilization - by the National Park Service at Mesa Verde, Chaco Canyon, and Aztec, and it was during this period that he came under the direction of Earl H. Morris, whose influence on his subsequent career was determinative.

During the first season of the Peabody $\mathrm{Mu}$ seum's Jeddito Expedition, in 1935, Bob served as surveyor and made the basic topographic map of the site of Awatovi. But in 1937 he returned to Three Oaks where he was employed by the Edward K. Warren Foundation to write The
Region of Three Oaks, a history of the area. Although focused on the local community, the book was a model for the story of countless similar communities in the Middle West and as such was a contribution to 19 th Century Americana. It was subsequently used as a text in the local schools. Later that same year he joined the staff of the Carnegie Institution of Washington, again under the direction of Earl Morris, and from 1938 to 1940 acted as surveyor, draftsman, and archaeologist in the excavation of the famous Basket Maker II dwellings near Durango, Colorado. Between field seasons he worked at Boulder, Colorado, and with Morris produced the classic report Anasazi Basketry, for which he did all the illustrations and much of the text. At the same time he completed the work for an A.B. degree at the University of Colorado, graduating in 1939 with honors and a Phi Beta Kappa key. Later he was elected to Sigma Xi.

During the winter of 1940-41 Bob was on the staff of the Carnegie expedition at Copan, Honduras, under the general direction of A. V. Kidder. And the next year he returned to Boulder as instructor in American, Roman, and Greek archaeology. This pedagogical beginning was curtailed, however, by the Army, into which he was inducted in 1942 and assigned, with the rank of Master Sergeant, to an artillery unit at Camp Haan, California. He was released because of ill health in 1944, but meanwhile had received a certificate from the Sperry Gyroscope Company as a qualified instructor in gun control methods. He continued in paramilitary service during 1945, however, compiling flying charts and landing procedures for military pilots.

After the war, Bob's career was broken by repeated illnesses and a variety of jobs, including engineering work for the Santa Fe Railway, and as head draftsman for an engineering firm in Lubbock, Texas. He then again returned to Boulder, where he became Curator of Anthropology of the University Museum under Hugo G. Rodeck. He directed a field expedition to Dinosaur National Monument and wrote a report on work that had been done there by himself and earlier by the late Charles R. Scoggin. $\mathrm{He}$ also initiated an excellent system of indexing the Museum's collections and contributed much to its exhibitions. For a short time in 1949 he did archaeological research at Gila Pueblo, at Globe, Arizona, but again his health compelled 
a period in the Veterans' Hospital in Denver, followed by rest and medical treatment in Michigan, New York, and Florida.

Early in 1951 he moved to Montgomery, Alabama, where he worked for several years in research and in writing about 100 ethnographic manuals for the Arctic-Desert-Tropic Information Center, with time out for the removal of gastric ulcers. In 1955 he moved to Tucson in search of a more sanguine climate and was employed for a period as surveyor and cartographer by the Trico Electric Company. But in the following year he became associated with the Peabody Museum West of the Pecos in Tucson in a definitive study of the ceramics from Awatovi, where he had worked more than 20 years before, and he was engaged in this work until his death. He also collaborated with Joe Ben Wheat in the preparation of the Southwestern section of $A b$ stracts of New World Archaeology.

In 1957 Bob married Elizabeth Gookin, who survives him, together with three brothers, Arthur E., of South Bend, Indiana; Raymond J., of Anaheim, California; and Milton D., of New York City.

The bare outline of Bob Burgh's life provides little real insight into the personal qualities that made for him a host of devoted friends over the years. It is not given to many people to combine in themselves such a catholicity of human associations with a truly remarkable intellectual capacity. There will be many who will remember Bob for his unaffected empathy with people in all walks of life, and there will be others who knew him as the possessor of a brilliant mind. His best friends knew both sides of him, and some will perhaps cherish his memory especially for the wry, scrupulously honest, but always gentle humor with which he viewed the human condition. Behind all was a steadfast courage in the face of great vicissitudes, and an intellectual honesty of glittering brightness.

There are few men with Bob's inherent intellectual powers, nor many with his far-ranging and insatiable thirst for knowledge. He read widely and wisely in almost every field, scientific and literary, and digested it all with a humane philosophy and a balanced appraisal that enabled him to bring to bear on any problem the wealth of wisdom that was stored in his mind. Certainly if he had been given even a modicum of bodily strength he would have been outstand- ing in his profession, both as a teacher, a writer, and an investigator.

Bob's abilities were not wholly intellectual, however, for he possessed a rare ingenuity and a practical mechanical sense. I remember when he was a student at Boulder that he constructed a planetarium in order to demonstrate to himself the precession of the equinoxes, and he was constantly devising ingenious and always useful gadgets for his own or other people's use. A pantograph developed on novel principles was invented at one point, but was not promoted because of the lack of necessary capital.

His published writings are limited in number but unqualified in excellence, and had he lived he would have added further outstanding contributions. As an archaeologist he was a "whole man," for he could do everything necessary to the fulfillment of a project: excavation, surveying, research, illustration, drafting, photography, and writing, and all with a breadth of learning and comprehension that few persons can command. Those who early saw his promise may take a satisfaction and a pride in the contemplation of their prescience and the realization that they have in part fulfilled themselves in him. For the countless others who knew and loved him the enrichment of their own lives will be its own reward.

WATSON SMITH

1939

The Region of Three Oaks. The Edward K. Warren Foundation. Three Oaks.

1941

Anasazi Basketry: Basket Maker II through Pueblo III [with Earl H. Morris]. Carnegie Institution of Washington, Publication 533. Washington

1948

The Archaeology of Castle Park, Dinosaur National Monument [with Charles R. Scoggin]. University of Colorado Studies, Series in Anthropology, No. 2. University of Colorado Press. Boulder.

1950

Comment on Taylor's "A Study of Archaeology." American Anthropologist, Vol. 52, No. 1, pp. 114-7. Menasha.

1954

Basket Maker II Sites near Durango, Colorado [with Earl H. Morris]. Carnegie Institution of Washington, Publication 604. Washington.

\section{7}

Review of: "Current Anthropology," edited by William L. Thomas, Jr. American Antiquity, Vol. 22, No. 3, p. 306. Salt Lake City.

Earl Halstead Morris, 1889-1956. American Anthropologist, Vol. 59, No. 3, pp. 521-3. Salt Lake City. 


\section{8}

Review of: "A History of the Ancient Southwest," by Harold S. Gladwin. American Antiquity, Vol. 23, No. 3, pp. 314-6. Salt Lake City.

Review of: "The Cultivation and Weaving of Cotton in the Prehistoric Southwestern United States," by Kate Peck Kent. American Antiquity, Vol. 24, No. 2, pp. 205-6. Salt Lake City.

Review of: "The Archaeology of Humbolt Cave, Churchhill County, Nevada," by Robert F. Heizer and Alex D. Krieger. American Journal of Archaeology, Vol. 62, pp. 251-2. Princeton.
1959

Reviews of: "An Archaeological Survey of the Fremont Area," by James H. Gunnerson, and "Two Fremont Sites and Their Position in Southwestern Prehistory," by Dee C. Taylor. American Antiquity, Vol. 24, No. 3, pp. 327-8. Salt Lake City.

Ceramic Profiles in the Western Mound at Awatovi, Northeastern Arizona. American Antiquity, Vol. 25, No. 2, pp. 184-202, 448. Salt Lake City.

\section{0}

Potsherds and Forest Fires in the Pueblo Country. Plateau, Vol. 33, No. 2, pp. 54-6. Flagstaff. 